\title{
Pengaruh Kinerja Keuangan, Ukuran Perusahaan Dan Manajemen Laba Terhadap Return Saham Dengan Kebijakan Dividen Sebagai Variabel Moderasi
}

\author{
Muhamad Nazhif Hawari', Zuwesty Eka Putri² \\ 1,2Universitas Islam Negeri Syarif Hidayatullah Jakarta \\ ²zuwesty.eka@uinjkt.ac.id
}

\begin{abstract}
This research aims to test influence of financial performance, company size and profit management on return of shares with dividend policy as moderation variable. This research was conducted in a manufacturing company registered in Indonesia Sharia stock index (ISSI) period 2016-2018. The sampling method in this study uses purposive sampling. The number of samples on this study was as many as 20 companies. The financial performance of the study is calculated by a debt to equity ratio. Hypothesis testing in this study used multiple regression methods and moderated regression analysis. The result of this research show the financial performance and company size has no effect on the stock return and earning management affects the stock return. Dividend policy is not able to moderate the influence of financial performance, company size and profit management on return of shares.
\end{abstract}

Keywords: financial performance, company size, profit management, stock return, dividend policy

\begin{abstract}
Abstrak
Tujuan dari penelitian ini adalah untuk menguji pengaruh kinerja keuangan, ukuran perusahaan dan manajemen laba terhadap return saham dengan kebijakan dividen sebagai variabel moderasi. Penelitian ini menggunakan sampel perusahaan manufaktur yang terdaftar di Indeks Saham Syariah Indonesia (ISSI) periode 2016-2018. Metode pengambilan sampel dalam penelitian ini menggunakan purposive sampling. Jumlah sampel pada penelitian ini adalah sebanyak 20 perusahaan. Kinerja keuangan dari penelitian ini dihitung dengan rasio hutang terhadap modal. Pengujian hipotesis dalam penelitian ini menggunakan metode regresi linear berganda dan moderated regression analysis. Hasil penelitian ini menunjukkan kinerja keuangan dan ukuran perusahaan tidak berpengaruh terhadap return saham dan manajemen laba berpengaruh terhadap return saham. Kebijakan dividen tidak mampu memoderasi pengaruh kinerja keuangan, ukuran perusahaan dan manajemen laba terhadap return saham.
\end{abstract}

Kata Kunci: Kinerja keuangan, ukuran perusahaan, manajemen laba, return saham, kebijakan dividen 


\section{PENDAHULUAN}

Indonesia sebagai salah satu negara muslim terbesar di dunia merupakan pasar yang menjanjikan untuk pengembangan industri keuangan syariah. Investasi syariah di pasar modal merupakan bagian dari industri keuangan syariah dan mempunyai peranan yang cukup penting untuk meningkatkan pangsa pasar industri keuangan syariah di Indonesia. Indeks Saham Syariah Indonesia (ISSI) merupakan salah satu indeks berbasis syariah di Bursa Efek Indonesia selain Jakarta Islamic Index (JII) yang diterbitkan oleh Bapepam-LK dan Dewan Syariah Nasional Majelis Ulama Indonesia (DSN-MUI) pada tanggal 12 Mei 2011. Konstituen ISSI adalah seluruh saham yang tergabung dalam Daftar Efek Syariah (DES) yang di review oleh OJK setiap enam bulan sekali (Mei dan November) dan tercatat di BEI. Hal yang melatarbelakangi terbentuknya ISSI adalah untuk memisahkan antara saham syariah dan non syariah yang dahulunya disatukan dalam Indeks Harga Saham Gabungan (IHSG). Cara ini diharapkan agar para investor muslim tertarik dan tidak takut menanamkan modalnya pada saham yang diragukan kehalalannya. Adapun setiap tahun tingkat kapitalisasi pasar ISSI dan JII terus mengalami kenaikan yang berarti semakin besar kapitalisasi pasar, maka semakin mahal perusahaan tersebut dihargai oleh pasar.

Tujuan investor dalam berinvestasi adalah memaksimalkan return, tanpa melupakan faktor resiko investasi yang harus dihadapinya. Return merupakan hasil yang diperoleh dari investasi. Return dapat berupa return realisasi yang sudah terjadi atau return ekpektasi yang belum terjadi tetapi diharapkan akan terjadi di masa mendatang. Return realisasi dihitung berdasarkan data historis. Return realisasi penting karena digunakan sebagai salah satu pengukur kinerja dari perusahaan. Return historis ini juga berguna sebagai dasar penentuan return ekspektasi (expected return) dan risiko di masa datang. Return ekspektasi (expected return) adalah return yang diharapkan akan diperoleh oleh investor di masa mendatang. Berbeda dengan return realisasi yang sifatnya sudah terjadi, return ekspektasi sifatnya belum terjadi (Retnaningrum dan Haryanto, 2018).

Ekspektasi dari para investor atau pemegang saham terhadap investasinya adalah memperoleh return (tingkat pengembalian) sebesar-besarnya dengan risiko tertentu. Oleh karena itu, investor memiliki kepentingan untuk mampu memprediksi berapa besar investasi mereka. Besar kecilnya return saham dipengaruhi oleh beberapa faktor diantaranya adalah manajemen laba, ukuran perusahaan, leverage dan kebijakan dividen (Adiwibowo, 2018).

Kinerja keuangan merupakan suatu analisis yang dilakukan untuk menilai sejauh mana suatu entitas telah melaksanakan menggunakan aturan-aturan pelaksanaan keuangan dengan baik dan benar misalnya dengan membuat laporan keuangan yang memenuhi standar dan ketentuan dalam SAK, GAAP atau ketentuan lainnya (Subagyo, 2017). Adiwibowo (2018) menyatakan bahwa semakin besar ukuran perusahaan akan mencerminkan perusahaan mempunyai kemampuan yang semakin besar untuk dapat membiayai kebutuhan dananya (kesempatan investasi) pada masa yang akan datang. Ukuran perusahaan juga dapat menjelaskan kemampuan perusahaan untuk mempertahankan kinerjanya pada saat terjadi perubahan yang mempengaruhi kinerja perusahaan tersebut. 
Selain kinerja keuangan dan ukuran perusahaan, manajemen laba juga merupakan faktor yang mempengaruhi return saham. Manajemen laba atau earnings management merupakan suatu kondisi dimana pihak manajemen ternyata tidak berhasil mencapai target laba yang ditentukan, maka manajemen akan memanfaatkan keleluasaan yang diperbolehkan oleh standar akuntansi dalam menyusun laporan keuangan untuk memodifikasi laba yang dilaporkan. Manajemen termotivasi untuk memperlihatkan kinerja yang baik dalam menghasilkan nilai atau keuntungan maksimal bagi perusahaan sehingga manajemen cenderung memilih dan menerapkan kebijakan akuntansi yang dapat memberikan informasi laba lebih baik (Adiwibowo, 2018).

Keputusan yang diambil oleh manajemen terhadap laba yang dihasilkan juga berpengaruh pada kebijakan mengenai besarnya dividen yang akan dibagikan kepada investor. Kebijakan dividen sering dianggap sebagai sinyal bagi investor dalam menilai baik buruknya perusahaan, hal ini disebabkan karena kebijakan dividen dapat membawa pengaruh terhadap harga saham perusahaan (Kurniawan, 2017). Penelitian yang dilakukan oleh Kurniawan (2017) menunjukkan bahwa kinerja keuangan tidak berpengaruh terhadap return saham dan kebijakan dividen tidak mampu memoderasi pengaruh leverage terhadap return saham.

Untuk memperkirakan return suatu saham, investor dapat melakukan pendekatan penilaian saham yang meliputi analisis fundamental dan analisis teknikal (Susanti, 2016). Analisis fundamental berkaitan dengan analisis terhadap laporan keuangan perusahaan yang merupakan cerminan dari kinerja keuangan perusahaan. Penelitian Abdullah et al. (2015) menemukan bahwa adanya hubungan yang signifikan antara leverage dan return saham. Hasil yang serupa juga dilakukan oleh penelitian (Adiwibowo, 2018) bahwa leverage berpengaruh signifikan terhadap return Saham. Berdasarkan uraian tersebut, maka dapat dirumuskan hipotesis penelitian sebagai berikut:

$\mathrm{H}_{1}$ : Kinerja keuangan berpengaruh terhadap return saham.

Ukuran perusahaan akan mencerminkan kemampuan perusahaan dalam membiayai kebutuhan dananya (kesempatan investasi) pada masa yang akan datang dan memberikan pengaruh positif bagi investasi (Adiwibowo, 2018). Ukuran perusahaan yang besar mempunyai sumber daya yang besar pula, tentunya akan melakukan kegiatan operasional yang semakin besar dan semakin besar pula pendapatan yang dihasilkan oleh perusahaan. Besarnya pendapatan yang diperoleh perusahaan akan berpengaruh positif terhadap laba dan tentu akan memberikan return yang cukup besar bagi pemegang saham. Pernyataan tersebut didukung oleh hasil penelitian yang dilakukan oleh Sudarsono dan Sudiyatno (2016) dan Adiwibowo (2018) yang memberikan kesimpulan bahwa ukuran perusahaan berpengaruh terhadap return saham. Berdasarkan uraian tersebut, maka dapat dirumuskan hipotesis penelitian sebagai berikut:

$\mathrm{H}_{2}$ : Ukuran Perusahaan berpengaruh terhadap return saham.

Dalam teori keagenan memberi penjelasan bahwa kebebasan manajemen dalam memilih kebijakan akuntansi dan aturan yang tepat sering memicu manajemen memilih kebijakan yang dapat memaksimalkan kepentingan mereka dan nilai pasar saham dan menimbulkan konflik kepentingan antara agen selaku manajemen dan prinsipal selaku 
pemilik. Manajemen laba merupakan suatu tindakan yang dilakukan manajemen akibat dari keleluasaan yang diperbolehkan oleh Standar Akuntansi Keuangan. Salah satu motivasi manajemen perusahaan melakukan praktik manajemen laba adalah untuk mendapatkan laba yang diharapkan oleh investor. Hasil dari penelitian Istiqomah dan Adhariani (2017) menunjukkan manajemen laba memiliki pengaruh terhadap imbal hasil saham atau stock return. Berdasarkan uraian tersebut, maka dapat dirumuskan hipotesis penelitian sebagai berikut:

$\mathrm{H}_{3}$ : Manajemen laba berpengaruh terhadap return saham.

Dividen memiliki atau mengandung informasi sebagai syarat prospek perusahaan. Semakin besar dividen yang dibagikan kepada pemegang saham, maka kinerja keuangan akan dianggap semakin baik, dan pada akhirnya penilaian terhadap perusahaan yang tercermin melalui harga saham juga akan semakin baik, begitu pula sebaliknya. Pengaruh kinerja keuangan khususnya leverage terhadap return saham dapat dikuatkan atau dilemahkan dengan kebijakan dividen sebagai variabel moderasi. Apabila leverage rendah maka dividen yang dibagikan kepada investor akan lebih besar, dan return saham akan tinggi. Namun, apabila leverage tinggi maka dividen yang dibagikan kepada investor rendah, dan return saham akan kecil. Dalam penelitian Adiwibowo (2018) menunjukkan bahwa kebijakan dividen dapat secara signifikan memoderasi pengaruh leverage terhadap pengembalian saham. Berdasarkan uraian tersebut, maka dapat dirumuskan hipotesis penelitian sebagai berikut:

$\mathrm{H}_{4}$ : Kebijakan dividen memoderasi berpengaruh kinerja keuangan terhadap return saham.

Kebijakan dividen sebagai variabel moderasi juga mempunyai peran memperkuat atau memperlemah pengaruh ukuran perusahaan terhadap return saham. Apabila ukuran perusahaan besar dan dividen yang dibagikan kepada pemegang saham besar, maka return saham juga akan besar. Namun sebaliknya, apabila ukuran perusahaan besar dan dividen yang dibagikan kepada pemegang saham kecil, maka return saham akan kecil. Hasil dari penelitian Sudarsono dan Sudiyatno (2016) menunjukkan bahwa ukuran perusahaan berpengaruh terhadap return saham. Berdasarkan uraian tersebut, maka dapat dirumuskan hipotesis penelitian sebagai berikut:

$\mathrm{H}_{5}$ : Kebijakan dividen memoderasi berpengaruh ukuran perusahaan terhadap return saham.

Kebijakan dividen menjadi pusat perhatian banyak pihak seperti pemegang saham, kreditor, maupun pihak eksternal lain yang memiliki kepentingan dari informasi yang dikeluarkan perusahaan (Adiwibowo, 2018). Apabila perusahaan melakukan manajemen laba dan dividen yang dibagikan kepada pemegang saham besar, maka return saham juga akan semakin besar. Hasil dari penelitian Adiwibowo (2018) menunjukkan bahwa Kebijakan Dividen dapat secara signifikan memoderasi pengaruh manajemen pendapatan terhadap return saham. Berdasarkan uraian tersebut, maka dapat dirumuskan hipotesis penelitian sebagai berikut:

$\mathrm{H}_{6}$ : Kebijakan dividen momoderasi pengaruh manajemen laba terhadap return saham. 


\section{METODE}

Populasi dalam penelitian ini adalah perusahaan yang terdaftar di BEI, sedangkan perusahaan yang terdaftar di BEI yang sesuai dengan kriteria yang dibuat merupakan sampel. Metode penentuan sampel dilakukan dengan teknik purposive sampling untuk menentukan kriteria khusus terhadap sampel. Sumber data yang digunakan menggunakan data sekunder dan metode yang digunakan yaitu metode pengumpulan data dengan cara menganalisis semua catatan informasi, dokumen dan studi pustaka. Data-data tersebut diperoleh dari website resmi BEI yaitu www.idx.co.id.

Berikut ini adalah operasionalisasi variabel yang digunakan dalam penelitian ini:

1. Kinerja Keuangan (X1)

Kinerja keuangan dapat dinilai dari beberapa rasio di antaranya rasio likuiditas, rasio aktivitas, rasio leverage, rasio profitabilitas, dan rasio pasar. Dalam penelitian ini, Kinerja Keuangan di proksikan menggunakan rasio leverage. Rasio leverage digunakan karena rasio leverage dapat mengukur sejauh mana aset perusahaan dibiayai dengan utang (Wijaya, 2017). Debt to equity ratio (DER) merupakan imbangan antara hutang yang dimiliki perusahaan dengan modal sendiri. Semakin tinggi rasio ini berarti modal sendiri semakin sedikit dibanding dengan hutangnya.

\section{DER = Total Hutang}

Modal

2. Ukuran Perusahaan (X2)

Ukuran perusahaan (Size) adalah suatu skala dimana dapat diklasifikasikan besar kecilnya perusahaan menurut berbagai cara, antara lain total aset, penjualan, log size, nilai pasar saham, kapitalisasi pasar, dan lain-lain yang semuanya berkorelasi tinggi (Wijaya, 2017). Dalam penelitian ini, ukuran perusahaan (Size) menggunakan Log Total Asset.

\section{Size $=$ Logaritma natural (Total Asset)}

3. Manajemen Laba (X3)

Dalam penelitian ini, manajemen laba dapat dihitung dengan menggunakan modified Jones model yang dikembangkan oleh (Dechow et al. 1995). Model tersebut lebih tepat digunakan untuk mengurangi dugaan kecenderungan dari Model Jones untuk mengukur akrual diskresioner dengan error ketika diskresi yang digunakan melebihi pendapatan. Modified Jones model dianggap sebagai model yang mampu mendeteksi adanya manajemen laba (Indrayanti dan Wirakusuma, 2017). Perhitungan manajemen laba dengan dengan menggunakan model tersebut sebagai berikut:

$$
D A_{i t}=\left(T A_{i t} / A_{i t-1}\right)-N D A_{i t}
$$

4. Kebijakan Dividen (X4)

Dividend payout ratio (DPR) merupakan rasio yang menunjukkan bagian atas laba yang diperoleh perusahaan nantinya akan dibayarkan kepada pemegang saham biasa berbentuk dividen kas. Kebijakan dividen dijadikan variabel moderasi dengan alasan bahwa kebijakan dividen selalu menjadi pusat perhatian banyak pihak baik investor, 
kreditor, dan pihak lain yang berkepentingan karena dividen mempunyai informasi yang sarat akan prospek perusahaan untuk kedepannya (Dewi et al, 2017). Menghitung kebijakan dividen dapat dengan cara:

\section{DPR = Dividend \\ Net Profit}

5. $\quad$ Return Saham (Y)

Abnormal return digunakan sebagai indikator dari stock return. Dalam penelitian ini digunakan cummulative abnormal return (CAR) untuk mengetahui reaksi pasar atas pengumuman atau informasi laba yang dikeluarkan atau dipublikasikan oleh perusahaan dan dijadikan sebagai proksi dari return saham atau stock return. CAR merupakan akumulasi dari abnormal return selama satu tahun (12 bulan). Penggunaan proksi ini sama dengan yang digunakan oleh Istiqomah dan Adhariani (2017) dan Uswati dan Mayangsari (2016). CAR dapat dicari dengan menggunakan persamaan berikut:

\section{$\operatorname{CAR}(\mathrm{t} 1, \mathrm{t} 2)=\sum A R t 1, t 2$}

Metode analisis pada penelitian ini menggunakan metode regresi linear berganda (model 1) untuk $\mathrm{H} 1, \mathrm{H} 2$ dan $\mathrm{H}_{3}$ dan MRA (model 2) untuk $\mathrm{H} 4, \mathrm{H} 5$, dan $\mathrm{H}_{6}$ variabel independen yang akan diteliti yaitu kinerja keuangan, ukuran perusahaan, dan manajemen laba sedangkan variabel dependennya adalah return saham dan ditambah dengan variabel moderasi yaitu kebijakan dividen. Model regresi yang akan digunakan untuk menguji hipotesis adalah sebagai berikut:

$$
\begin{aligned}
& \mathrm{CAR}=\mathrm{a}+\beta_{1} \mathrm{DER}+\beta_{3} \mathrm{Size}+\beta_{4} \mathrm{DA}+\beta_{5} \mathrm{DPR}+\varepsilon \\
& \mathrm{CAR}=\mathrm{a}+\beta_{1} \mathrm{DER}+\beta_{3} \mathrm{Size}+\beta_{4} \mathrm{DA}+\beta_{5} \mathrm{DPR}+\beta_{6} \mathrm{DER} * \mathrm{DPR}+\beta_{8} \mathrm{Size}^{*} \mathrm{DPR}+\beta_{9} \mathrm{DA} * \mathrm{DPR} \\
& +\varepsilon
\end{aligned}
$$

Keterangan:
$\mathrm{a} \quad=$ Konstanta
$\mathrm{DA}=$ Manajemen Laba
$\beta=$ Koefisien regresi
DPR $=$ Kebijakan Dividen
DER = Leverage $($ Kinerja Keuangan $)$
$\mathrm{CAR}=$ Return Saham
Size $=$ Ukuran Perusahaan
$\varepsilon \quad=$ Residual Error

\section{HASIL DAN PEMBAHASAN}

Penelitian ini menggunakan data sekunder yang diperoleh dari website resmi Bursa Efek Indonesia (BEI). Penelitian ini menggunakan populasi perusahaan yang termasuk dalam Indeks Saham Syariah Indonesia pada sektor manufaktur di Bursa Efek Indonesia (BEI) selama periode 2016-2018. 


\section{Hasil Uji Statistik Deskriptif}

Statistik deskriptif memberikan gambaran atau deskripi suatu data yang dilihat dari nilai rata-rata (mean), standar deviasi, varian, maksimum, minimum. Kemudian, dengan melihat nilai mean dan standar deviasi dapat memberikan gambaran mengenai kualitas data. Berikut hasil statistik deskriptif:

Tabel 1. Hasil Uji Statistik Deskriptif

\begin{tabular}{lccccc}
\hline & N & Minimum & Maximum & Mean & Std. Deviation \\
\hline CAR & 60 & -.63 & .79 & -.0129 & .28370 \\
DER & 60 & .08 & 1.83 & .5368 & .35577 \\
Size & 60 & 26.25 & 32.20 & 29.0148 & 1.42358 \\
DA & 60 & -.12 & .27 & .0590 & .07394 \\
DPR & 60 & .01 & 2.25 & .4798 & .42535 \\
Valid N (listwise) & 60 & & & & \\
\hline
\end{tabular}

Sumber: Data diolah.

Dari data pada tabel 1 dapat diketahui bahwa jumlah data yang digunakan adalah 60 data. Nilai return saham yang dihitung menggunakan proksi Cumulative Abnormal Return (CAR) menunjukkan nilai minimum -0,63 dan maksimum 0,79. Rata-rata nilai Return Saham adalah -0,0129 dengan standard deviasi sebesar 0,28370. Hasil tersebut mengungkapkan bahwa return saham pada penelitian ini cenderung mengalami capital loss. Hasil statistik deskriptif dari variabel kinerja keuangan yang dihitung dengan menggunakan rasio leverage atau Solvabilitas dengan proksi Debt to Equity Ratio (DER) menunjukkan nilai minimum sebesar 0,08 dan maksimum sebesar 1,83. Rata-rata nilai Kinerja Keuangan adalah 0,5368 dengan standar deviasi sebesar 0,35577. Dari hasil tersebut menunjukkan bahwa rata-rata perusahaan memiliki rasio DER dibawah angka 1 yang artinya perusahaan-perusahaan tersebut sehat secara keuangan. Sementara itu, variabel ukuran perusahaan yang dihitung dengan menggunakan Logaritma natural Total Aset (Size) menunjukkan nilai minimum sebesar 26,25 dan nilai maksimum sebesar 32,20. Rata-rata nilai Ukuran Perusahaan adalah 29.0148 dengan standar deviasi sebesar 1.42358. Dari hasil tersebut diatas mengungkapkan bahwa ukuran perusahaan pada penelitian tidak memiliki kesenjangan yang terpaut jauh dan relatif setara. Untuk variabel Manajemen Laba yang dihitung dengan menggunakan Diskresioner Akrual (DA) menunjukkan nilai minimum sebesar -0,12 dan maksimum sebesar 0,27. Rata-rata nilai Manajemen Laba adalah 0,0590 dengan standar deviasi sebesar 0,07394. Hasil ini mengungkapkan bahwa rata-rata perusahaan melakukan manajemen laba sebesar 5\%. Sedangkan variabel Kebijakan Dividen yang dihitung dengan menggunakan Dividen Payout Ratio (DPR) menunjukkan nilai minimum sebesar 0,01 dan maksimum sebesar 2,25. Rata-rata nilai Kebijakan Dividen adalah 0,4798 dengan standar deviasi sebesar 0,42535. Hasil tersebut menunjukkan bahwa rata-rata melakukan pembagian dividen sebesar $47 \%$ dari net profit. 


\section{Hasil Uji Asumsi Klasik}

Pada penelitian ini dilakukan uji asumsi klasik yaitu uji normalitas data, uji autokorelasi, uji multikolonieritas, dan uji heterokedasitas. Semua uji asumsi klasik yang dilakukan telah memenuhi seluruh syarat untuk setiap uji tersebut.

\section{Hasil Uji Hipotesis}

\section{Uji Koefisien Determinasi $\left(\mathbf{R}^{2}\right)$}

Hasil uji koefisien determinasi $\left(\mathrm{R}^{2}\right)$ disajikan pada tabel berikut:

Tabel 2. Hasil Uji Koefisien Determinasi $\left(R^{2}\right)$

\begin{tabular}{ccccc}
\hline Model & R & R Square & Adjusted R Square & $\begin{array}{c}\text { Std. Error of the } \\
\text { Estimate }\end{array}$ \\
\hline 1 & $.471^{\mathrm{a}}$ & .222 & .165 & .25920 \\
2 & $.530^{\mathrm{a}}$ & .281 & .184 & .205628 \\
\hline
\end{tabular}

Sumber: Data diolah.

Model 1 pada tabel 2 menunjukkan bahwa nilai Adjusted R Square sebesar 0,165, yang berarti bahwa sebesar 16,5\% variabel Return Saham dijelaskan oleh variabel Kinerja Keuangan, Ukuran Perusahaan, dan Manajemen Laba. Sisanya yaitu 83,5\% dijelaskan oleh faktor-faktor selain variabel yang digunakan dalam penelitian ini. Sementara itu, pada model 2 terjadi kenaikan Adjusted R Square dengan nilai 0,184 atau sebesar $18,4 \%$ dan sisanya sebesar $81,6 \%$ dijelaskan oleh faktor lain selain variabel yang digunakan dalam penelitian ini.

\section{Hasil Uji F}

Hasil F disajikan pada tabel berikut:

Tabel 3. Hasil Uji F

\begin{tabular}{clccccc}
\hline & Model & $\begin{array}{c}\text { Sum of } \\
\text { Squares }\end{array}$ & df & $\begin{array}{c}\text { Mean } \\
\text { Square }\end{array}$ & F & Sig. \\
\hline \multirow{2}{*}{1} & Regression & 1.053 & 4 & .263 & 3.920 & .007 \\
& Residual & 3.695 & 55 & .067 & & \\
& Total & 4.749 & 59 & & & \\
\hline
\end{tabular}

Sumber: Data diolah.

Hasil uji F pada tabel 3 menunjukan bahwa nilai signifkansi sebesar 0,007 yang berarti $<0,05$. Maka model penelitian ini sudah fit dan juga secara bersama-sama yang artinya variabel independen yaitu kinerja keuangan, ukuran perusahaan, manajemen laba, dan kebijakan dividen secara bersama-sama berpengaruh secara simultan terhadap variabel dependen yaitu return saham. 


\section{Hasil Uji t}

Hasil t disajikan pada tabel berikut:

Tabel 4. Hasil Uji $t$

\begin{tabular}{cccc}
\hline Model & Variabel & B & Sig. \\
\hline 1 & Constant & .471 & .528 \\
& DER & -.109 & .268 \\
Size & -.017 & .504 \\
& DA & 1.474 & .004 \\
2 & DPR & -.025 & .764 \\
& Constant & 1.269 & .389 \\
& DER & -.012 & .928 \\
& Size & -.046 & .344 \\
& DA & 2.139 & .026 \\
& DPR & -1.783 & .520 \\
& DER*DPR & -.226 & .314 \\
& Size*DPR & .064 & .471 \\
& DA*DPR & -2.146 & .344 \\
\hline
\end{tabular}

Sumber: Data diolah.

Persamaan regresi berganda model 1 dan persamaan MRA model 2 yang terbentuk dalam penelitian ini adalah:

\section{Model 1:}

CAR $=0,471-0,109$ DER $-0,017$ Size $+1,474$ DA

\section{Model 2:}
CAR $=$ 1,269 - 0,012 DER - 0,46 Size + 2,139 DA - 1,783 DPR - 0,226 DER*DPR +0,064 Size*DPR - 2,146 DA*DPR

Berdasarkan hasil penelitian pada tabel 4, model 1, diperoleh nilai signifikansi variabel kinerja keuangan sebesar 0,268, yang berarti variabel kinerja keuangan dengan proxy leverage (DER) tidak berpengaruh terhadap return saham, oleh karena itu, $\mathrm{H}_{1}$ ditolak. Beberapa indikasi yang dapat menyebabkan pengujian ini tidak memiliki pengaruh adalah investor tidak tertarik terhadap informasi tinggi rendahnya rasio hutang perusahaan karena perusahaan yang memiliki rasio leverage rendah tidak menjamin harga saham perusahaan tersebut akan selalu naik. Dalam penelitian ini, rasio leverage cukup rendah dengan rata-rata 0,53 akan tetapi harga saham mengalami penurunan 
yaitu sebesar 1\% sehingga tinggi rendahnya rasio leverage tidak mempengaruhi harga saham perusahaan tersebut. Menurut Kurniawan (2017) disebutkan bahwa Debt to equity ratio tidak mempengaruhi harga pada perusahaan yang listing di Bursa Efek. Sementara itu, variabel ukuran perusahaan memiliki nilai sig. sebesar 0,504 yang berarti variabel ukuran perusahaan tidak berpengaruh terhadap return saham. Hal ini mengindikasikan bahwa $\mathrm{H}_{2}$ ditolak. Naik dan turunnya harga saham tidak dipengaruhi oleh faktor besar kecilnya suatu perusahaan. Pada penelitian ini contohnya pada tahun 2018 saham INTP memiliki nilai ukuran perusahaan sebesar 30,9 dari rata-rata ukuran perusahaan 29 mengalami penurunan saham sebesar 3\%. Dan pada tahun yang sama saham SIDO dengan nilai ukuran perusahaan sebesar 28,8 mengalami kenaikan harga saham sebesar $49 \%$. Sedangkan variabel manajemen laba memiliki nilai sig. sebesar 0,004, berarti variabel manajemen laba berpengaruh terhadap return saham. Oleh karena itu, $\mathrm{H}_{3}$ diterima. Peran manajemen dalam menentukan laba akrual atau diskresioner akrual salah satunya yaitu untuk menarik para investor untuk menanam sahamnya di perusahaan tersebut. Dengan banyaknya investor, diharapkan harga saham perusahaan meningkat dan memberikan return yang diharapkan bagi investor.

Hasil yang diperoleh pada model 2 di tabel 4, menunjukkan bahwa variabel kebijakan dividen tidak mampu memoderasi kinerja keuangan terhadap return saham atau $\mathrm{H}_{4}$ ditolak. Hal ini dibuktikan dengan nilai sig. sebesar 0,314. Indikasi penyebab tidak berpengaruhnya kebijakan dividen dalam memoderasi kinerja keuangan terhadap return saham salah satunya yaitu rasio leverage atau kemampuan perusahaan untuk memenuhi kewajiban jangka panjangnya tidak mempengaruhi harga saham perusahaan sektor manufaktur yang terdaftar di ISSI periode 2016-2018. Sementara itu, variabel kebijakan dividen juga tidak mampu memoderasi hubungan antara ukuran perusahaan terhadap return saham atau $\mathrm{H}_{5}$ ditolak, ditunjukkan dengan nilai sig. sebesar 0,471 Periode dan sampel penelitian ini menjadi indikasi utama tidak berpengaruhnya kebijakan dividen untuk memoderasi ukuran perusahaan terhadap return saham. Perusahaan yang besar belum tentu menghasilkan gain dan perusahaan kecil belum tentu loss. Begitu pula kebijakan dividen tidak mampu memoderasi hubungan manajemen laba terhadap return saham atau $\mathrm{H}_{6}$ ditolak (nilai sig. sebesar 0,955). Salah satu indikasi atau penyebab tidak berpengaruhnya kebijakan dividen dalam memoderasi manajemen laba terhadap return saham yaitu terbatasnya sampel dan ruang lingkup penelitian sehingga tidak mendapatkan hasil yang signifikan.

\section{SIMPULAN}

Berdasarkan penelitian yang telah dilakukan, dapat disimpulkan beberapa hasil, yaitu kinerja keuangan dan ukuran perusahaan tidak berpengaruh terhadap return saham dan manajemen laba berpengaruh terhadap return saham. Kebijakan dividen tidak mampu memoderasi pengaruh kinerja keuangan, ukuran perusahaan dan manajemen laba terhadap return saham.

Dengan adanya penelitian ini diharapkn dapat memberikan tambahan wawasan dan informasi bagi perusahaan dan investor tentang faktor yang mempengaruhi retrun saham. 
Keterbatasan dalam penelitian ini yaitu hanya menggunakan sektor manufaktur yang terdaftar di ISSI. Oleh karena itu, untuk peneliti selanjutnya diharapkan dapat menambah jumlah sampel atau mencari faktor lain yang mempengaruhi return saham.

\section{PUSTAKA ACUAN}

Abdullah, M. N., Parvez, K., Karim, T., dan Tooheen, R. B. 2015. "The impact of financial leverage and market size on stock returns on the Dhaka stock exchange: Evidence from selected stocks in the manufacturing sector". International Journal of Economics, Finance and Management Sciences, 10-15 .

Adiwibowo, A. S. 2018. "Pengaruh Manajemen Laba, Ukuran Perusahaan Dan Leverage Terhadap Return Saham Dengan Kebijakan Dividen Sebagai Variabel Moderasi". Jurnal Ilmiah Akuntansi Universitas Pamulang Vol. 6, No. 2, 203-222.

Dewi, L. S., Budiartha, I. K., dan Suputra, I. D. 2017. "Kebijakan Dividen Sebagaivariabel Moderasi Pengaruh Tax, Leverage Dan Firm Size Pada Earnings Management". E-Jurnal Ekonomi dan Bisnis Universitas Udayana 6.1, 277-302.

Indrayanti, N. P., dan Wirakusuma, M. G. 2017. "Pengaruh Manajemen Laba Pada Return Saham Dengan Kualitas Audit Dan Corporate Governance Sebagai Variabel Pemoderas"i. E-Jurnal Akuntansi Universitas Udayana, 1762-1790 .

Istiqomah, A., dan Adhariani, D. 2017. "Pengaruh Manajemen Laba terhadap Stock Return dengan Kualitas Audit dan Efektivitas Komite Audit sebagai Variabel Moderasi”. Jurnal Akuntansi dan Keuangan, Vol. 19, No. 1, 1-12

Jensen, M. C., dan Meckling, W. H. 1976. "Theory Of The Firm: Managerial Behavior, Agency Costs And Ownership Structure". Journal of Financial Economics 3, 305-360.

Kurniawan, A. 2017. "Pengaruh Kinerja Keuangan Terhadap Return Saham Dengan Menjadikan Kebijakan Dividen Sebagai Variabel Moderate Pada Perusahaan Yang Terdaftar Di Jakarta Islamic Indeks ( JII 2007 - 2011)". Akuisisi - Jurnal Akuntansi Vol. 13, 1-14.

Retnaningrum, M., dan Haryanto, T. 2018. "Analisis Pengaruh Kebijakan Dividen Dan Leverage Terhadap Return Saham Dengan Pemoderasi CSR". Jurnal Fakultas Ekonomi dan Bisnis Universitas Muhammadiyah Purwokerto , 1-9.

Subagyo. 2017. "Efek Mediasi Kinerja Perusahaan Pada Pengaruh Manajemen Laba Riil dan Ukuran Perusahaan Terhadap Return Saha”. JURNAL ONLINE INSAN AKUNTAN, Vol.2, No., 283 - 304 .

Susanti. 2016. "Pengaruh Cr Dan Roe Terhadap Return Saham Dengan Kebijakan Dividen Sebagai Variabel Intervening". Jurnal Pendidikan dan Ekonomi, Volume 5, Nomor 3, 228-236.

Uswati, L., dan Mayangsari, S. 2016. "Pengaruh Manajemen Laba Terhadap future Stock Return Dengan Asimetri Informasi Sebagai Variabel moderating”. Ekuitas: Jurnal Ekonomi dan Keuangan-Volume 20, Nomor2, 242-259. 
Wijaya, R. 2017. "Kinerja Keuangan dan Ukuran Perusahaan terhadap Harga Saham dengan Kebijakan Dividen sebagai Variabel Intervening". Jurnal Keuangan dan Perbankan, 21(3), 459-472. 